\title{
Proteomic analysis of long term salt responsive proteins in the halophyte Suaeda maritima
}

\author{
Shrikanth Saraswathi Krishnamurthi ${ }^{1}$, Suja George ${ }^{1}$, Sankaramasubramanian Meenakshisundram ${ }^{1}$, \\ Ajay Parida ${ }^{1,2 *}$
}

${ }^{1}$ Department of Plant Molecular Biology, M.S. Swaminathan Research Foundation, Taramani Institutional Area, Chennai 600 113, India

${ }^{2}$ Institute of Life Science, Bhubaneswar 751023, India

*Corresponding author email: shrihalo@gmail.com; drajayparida@gmail.com

\begin{abstract}
A proteomic approach was carried out to identify proteins responsive to long term salt treatment in the halophyte Suaeda maritima. A 3 -month-old S. maritima seedlings were hydroponically exposed to Modified Hoagland's treated with salt solution of $200 \mathrm{mM}$ were grown for a period of 14 days in a growth chamber maintained at $24 \pm 3^{\circ} \mathrm{C}, 70-75 \%$ relative humidity with $14 \mathrm{~h}$ light $(200 \mu \mathrm{mol} \mathrm{m}$ $\left.\mathrm{s}^{-1}\right) / 10 \mathrm{~h}$ dark cycle. The untreated set maintained in Modified Hoagland's solution was considered as control with similar conditions. Proteins extracted from the leaves of $S$. maritima control and salt treated seedlings were separated by Two-Dimensional gel electrophoresis (2DE). Using PDquest software analysis, we observed $\sim 50$ protein spots were reproducibly detected on gels, out of which 18 differentially expressed protein spots showed at least two-fold differences on 2DE maps some of them were up-regulated and few others were down-regulated in treated compared with the control. From that, we identified 6 up-regulated protein spots shows the maximum level of fold differences and these protein spots were performed trypsin digestion and Matrix Assisted Laser Desorption Ionization -Time of Flight (MALDI-TOF) analysis. The results showed that $S$. maritima could withstand up to $200 \mathrm{mM}$ $\mathrm{NaCl}$ for long term period of 14 days by up regulating proteins that are mainly involved in protein transport, vesicle trafficking, heme/iron binding, protein folding and assembly, chromosome segregation, cell maintenance. Our study has identified salt responsive proteins such as $R A B 2 B, C Y P 71 A 8, S C C 3$ that are not previously identified by expressed sequence tag analyses or transcriptome analyses in this species. This is the first report of proteome analysis and provides insights into the molecular mechanisms of long term salt tolerance in S. maritima.
\end{abstract}

Keywords: Suaeda maritima, halophyte, salt response, proteomics.

Abbreviations: 2DE_Two Dimensional gel electrophoresis, MALDI-TOF/MS_Matrix Assisted Laser Desorption Ionization Time of Flight/Mass Spectrometry, ROS_Reactive Oxygen Species, PMSF_Phenyl methyl sulfonyl fluoride, SDS_Sodium dodecyl sulfate.

\section{Introduction}

Abiotic stresses such as drought, salinity, heat, cold, flood etc are the major impediments of plant growth and metabolism that ultimately disturbs plant life (Ahmad and Prasad, 2012). Anthropogenic activities exacerbate these stress conditions to a greater extent and make a serious threat to the environment. Among these, salinity is one of the most critical abiotic stresses that adversely affect plant germination, growth and ultimately yield (Golldack et al., 2014). It has been estimated that $20 \%$ of cultivated lands are affected by soil salinity (Zhang et al., 2012). Furthermore, the salinized areas are increasing at a rate of $10 \%$ annually for various reasons, including low precipitation, high surface evaporation, weathering of native rocks, irrigation with saline water, and poor cultural practices. It has been estimated that more than $50 \%$ of the arable land would be salinized by the year 2050 (Jamil et al., 2011). In this context, developing crop plants that can sustain productivity under salinity stress conditions become important.

Plants differ in their responses to salinity stress depending on species, organs and developmental stages. Halophytes are naturally evolved salt-tolerant plants that can grow in environments that inhibit the growth of most glycophytic crop plants substantially (Ramani et al., 2006). Depending on their tolerance and demands for sodium salts, the halophytes can be distinguished as obligate and facultative halophytes. Obligate halophytes need some salt for their growth and development are characterized by low morphological and taxonomical diversity with relative growth rates increasing up to $50 \%$ in seawater. Facultative halophytes are found in less saline habitats along the border between saline and nonsaline upland and are characterized by broader physiological diversity which enable them to survive with saline and nonsaline conditions (Parida and Jha, 2010). The survival strategies of halophytes in high salt condition include various mechanisms such as; (1) selective accumulation or exclusion of ions (Mahajan and Tuteja, 2005); (2) compartmentalization of ions at the cellular and whole plant levels (Shabala and Mackay, 2011); (3) biosynthesis of compatible solutes and osmoprotectants (Gagneul et al., 2007; Slama et al., 2015); (4) activation and synthesis of antioxidant enzyme and compounds (Wang et al., 2013); (5) change in photosynthetic pathway (Uzilday et al., 2015); (6) induction and modulation of plant hormones (Parida and Das, 2005; Gupta and Huang, 2014). Thus, halophytes are an essential genetic resource for studies to understand mechanisms of salt 
stress tolerance, and to isolate candidate genes for improving salinity stress tolerance in glycophytes.

Suaeda maritima is an herbaceous, succulent, facultative annual halophyte which is native to saline soils of arid and semiarid regions. This species is a self-pollinated bisexual dicot of the family Chenopodiaceae with $2 n=36$ chromosomes and produces reddish brown seeds. It exhibits high tolerance to salt without having special salt secreting structures like salt glands or bladders on its leaves. $S$. maritima accumulates $\mathrm{Na}^{+}$in shoot vacuoles thus reducing the toxicity of $\mathrm{Na}^{+}$in the cytoplasm and limiting the osmotic potential of vacuoles to preserve cellular turgor pressure and expansion under high salt conditions.

Proteins play a crucial role in making the halophytes tolerant to salt stress and minimizing the adverse effects of $\mathrm{Na}^{+}$. Proteomics studies are an ideal way of identifying proteins that function in salt stress tolerance (Ghosh and $\mathrm{Xu}$, 2014). Two Dimensional Gel Electrophoresis (2DE) is an efficient proteomic approach have been extensively used for studying protein profiles of plants under stress to reveal the specific proteins contributing to the salt tolerance and survival of the halophytes in saline conditions. Previously, salt stress-related proteomic analyses are reported in many halophytes such as Suaeda aegyptiaca (Askari et al., 2006), Bruguiera gymnorrhiza (Tada and Kashimura, 2009), Salicornia europaea (Wang et al., 2009), Aeluropus lagopoides (Sobhanian et al., 2010), Puccinellia tenuiflora (Yu et al., 2011), Cakile maritima (Debez et al., 2012), Thellungiella halophila (Wang et al., 2013), Kandelia candel (Wang et al., 2014), Halogeton glomeratus (Wang et al., 2015), Tangut Nitraria (Cheng et al., 2015) etc. These studies have identified several salt responsive proteins which contribute to various functions such as photosynthesis, osmotic and ionic homeostasis, signal transduction, Reactive Oxygen Species (ROS) scavenging systems etc. However, there is no report on proteomic analysis of salt tolerance mechanism in S. maritima as yet.

In the present paper, we employed 2DE to identify proteins that are differentially expressing under salt treated conditions in S. maritima. Further, we analyzed few of these proteins by Matrix Assisted Laser Desorption Ionization -Time of Flight/Mass Spectrometry (MALDI-TOF/MS). Our results provide insights to the possible mechanisms of salt stress tolerance in this species at the molecular level.

\section{Results and Discussion}

\section{Effect of salt treatment on S. maritima}

Halophytes are specialized plants with well adapted morphological, anatomical and physiological characteristics that enable them to survive under high soil salt concentrations (Flowers and Colmer, 2008). We analyzed the proteomic responses of a $\mathrm{C} 3$ halophyte $S$. maritima under long term salt treatment to identify proteins that help the species to survive under salinity conditions.

The exposure of $S$. maritima seedlings to different $\mathrm{NaCl}$ concentrations resulted in various morphological changes in the leaves overtime. The plants displayed a linear decrease in leaf number and size under salt concentrations of 300 to $500 \mathrm{mM}$. At $500 \mathrm{mM} \mathrm{NaCl}$, the plants showed signs of severe stress at later stages of treatment. At 100 and $200 \mathrm{mM} \mathrm{NaCl}$, the plants continued to grow comparatively similar or better than the control plants. Thus, our results show that while three month old $S$. maritima can withstand lower salt concentrations, higher concentrations above $200 \mathrm{mM}$ affect its growth over long periods (Fig. S1).
Two-dimensional electrophoresis analysis of total proteins in $S$. maritima leaves

To investigate the long-term changes of protein profiles after treatment with salt, we carried out 2DE analysis of the total proteins in $S$. maritima leaves from 3 biological replicates. For each sample, triplicate gels were performed and they showed a high level of reproducibility. Around 50 protein spots were repeatedly detected on gels for both treated and control group. Quantitative image analysis revealed that a total of 18 protein spots changed their intensities significantly $(P<0.05)$ by more than 2 -fold in the treated samples compared with the control. Among the 18 differentially accumulated protein spots, 9 were more abundant and 6 less abundant in salt treated samples compared to control, and 3 spots appeared only in the control samples and were absent after salinity treatment as shown in Fig. $1 \& 2$.

\section{Identification of differentially expressed proteins by MALDI-TOF analysis}

Out of the 9 highly accumulating proteins spots in salt treated samples compared to control, 6 were analyzed by MALDITOF/MS analysis. After similarity searches, they were identified to be Ras related $R A B 2 B$, SNARE-interacting protein KEULE, Sister chromatid cohesion protein 3, Cytochrome P450 71A8, 16.6 KDa heat shock protein (Table $1 \& 2$ ). Localization and function distribution of identified proteins as shown in Fig. 3.

\section{Ras related $R A B 2 B$}

Ras related proteins constitute a super family of eukaryotic proteins which are thought to play a key role in the regulation of diverse cellular processes. This relatively small, monomeric protein $(20-25 \mathrm{kDa})$ binds GTP and has an intrinsic GTPase activity. Ras GTPases function as GDP/GTP regulated molecular switches (Vetter and Wittinghofer, 2001).They share a set of conserved G box GDP/GTP binding motif elements and is controlled by two main classes of regulatory proteins such as Guanine nucleotide exchange factors (GEFs) and GTPase activating proteins (GAPs).These two nucleotide bound states have similar conformations but pronounced differences corresponding to the switch I (Ras residues 30-38) and switch II (59-67) regions. The Ras protein member of this family is divided into five major branches on the basis of sequence and functional similarities: Ras, Rho, Rab, Ran and Arf. Among these, Rab proteins are the largest branch of the super family (Pereira Leal and Seabra, 2001). Rab GTPases are regulators of intracellular vesicular transport and trafficking of proteins between different organelles of the endocytic and secretory pathways. It facilitates vesicle formation and budding from the donor compartment, transport to the acceptor compartment, and then release of the vesicle content into the acceptor compartment. Rab proteins localization is dependent on prenylation and its specificity is dictated by divergent $\mathrm{C}$ terminal sequences (Zerial and McBride, 2001; Suja and Ajay, 2011). Specific Rab proteins have been found associated with the endoplasmic reticulum (Rab1), the post endoplasmic reticulum and pre-Golgi compartment (Rab2), different parts of the Golgi apparatus (Rab6), the plasma membrane (Rab5), early (Rab5, Rab4) and late (Rab7) endosomes (Batch, 1990). Previous studies reported that ypt homolog 3 in Zea mays sharing a GTP binding and activation property with the members of Ras family and show $97 \%$ similarity which plays a significant role in vacuolar 
trafficking and exocytosis (Palme et al., 1992). In the present study, we found $R A B 2 B$ (spot no.1) protein shows high similarity to $Z$. mays might probably be located in the ERGolgi membrane and could be involved in regulation of vesicular transport and delivery of proteins to the cell surface for acquiring stress tolerance.

\section{SNARE interacting protein KEULE}

SNARE (Superfamily of $N$-ethylmaleimide sensitive factor adaptor protein receptor) domain containing proteins are key players in vesicle-associated membrane fusion during transport processes between individual compartments of the endomembrane system. It plays a vital role in higher plants and is involved in various fundamental processes such as cytokinesis, gravitropism, pathogen defense, symbiosis, and abiotic stress responses (Lipka et al., 2007). SNARE proteins comprise small (200-400 amino acid) polypeptides that are characterized by the presence of a particular peptide domain called the SNARE motif (Jahn and Scheller, 2006). SNAREs can be classified either on the basis of their sub cellular localization (functional classification) or occurrence of invariant amino acid residues in the center of the SNARE motif (structural classification). Functional classification divides into vesicle-associated and target membraneassociated SNAREs ( $\mathrm{v}$-and t-SNAREs) and the structural classification can be grouped as Q- and R-SNAREs (Sollner et al., 1993; Fasshauer et al., 1998). Generally, t-SNAREs correspond to Q-SNAREs, and v-SNAREs correspond to RSNAREs. The target membrane localized Q-SNAREs can be further subdivided into Qa, Qb and Qc-SNAREs (Bock et al., 2001). Due to greater diversification of SNARE isoforms in plants, it reflect the necessity for some SNAREs to be devoted to plant specific biological processes such as cytokinesis, gravitropic responses, and the transport of phytohormones etc. In Arabidopsis SNAREs genome contains six members of the Secl family, of which one, KEULE (KEU), has been reported to be involved in cytokinesis (Assaad et al., 2001) and this protein (spot no.3\&5) were identified twice in our 2DElectophoresis experiment. This happens due to post-translational modifications such as glycosylation, phosphorylation, oxidation, etc. was also previously reported in Arabidopsis (Ndimba et al., 2005). Secl KEULE proteins are known regulators of SNARE domain and involved in promoting vesicle fusion in the cell division plane which may helps to obtain a stress tolerance.

\section{Sister chromatid cohesion protein 3 (SCC3)}

Structural maintenance of chromosome (SMC) proteins plays a critical role in chromosome folding and dynamics. Eukaryotic SMC proteins can be divided into three classes: condensins, cohesin complexes, DNA recombination and repair complexes (Michaelis et al., 1997). Of these, sister chromatid cohesion is well established along the entire length of the chromosome at the time of DNA replication and persists throughout the G2 phase (Biggins and Murray, 1998). It is mediated, in part, by a group of four highly conserved proteins, referred to as the cohesion complex (SMC1, SMC3, $S C C 1$ and SCC3) which is utilized by a wide range of organisms. The cohesion complex proteins present in the nuclear matrix are involved in chromosome organization and the establishment of chromosome boundaries. The cohesion protein SCC3 was first identified as a member of the yeast mitotic cohesin complex (Toth et al., 1999) and was subsequently identified in Caenorhabditis elegans and
Arabidopsis (Pasierbek et al., 2003; Wang et al., 2003).This SCC3 protein (spot no.4) was identified in our study shows $12 \%$ amino acid sequence homology with Arabidopsis. In Arabidopsis, SCC3 protein expressed in roots, mature leaves and is mainly involved in both meiotic and mitotic divisions. The localization pattern of this protein during meiosis is very similar to that REC8 in yeasts, and to be mainly concerned for orientation and centromere cohesion at anaphase. Hence, $S C C 3$ proteins are necessary not only to maintain centromere cohesion, but also for the monopolar orientation of the kinetochores during meiosis.

\section{Cytochrome P450 71A8 (CYP 71A8)}

Cytochrome P450 catalyzes the monooxygenation of a variety of hydrophobic substrates which includes steroid hormones, prostaglandins, procarcinogens, and active pharmacological compounds. P450s can be broadly classified into two classes based on sequence homology and the identity of their redox partner protein. The class I enzyme $\mathrm{P} 450$ s (bacterial/ mitochondrial) receive their NADH-derived (bacterial) or NADPH derived (mitochondrial) electrons from a two-protein redox chain, (FAD reductase iron sulfur protein P450); the class II enzymes (membrane bound eukaryotic microsomal) receive NADPH derived electrons directly from an FAD/FMN-containing reductase (Hasemann et al., 1995). Plant cytochromes P450s include a highly diverse array of protein sequences possessing common catalytic chemistry but different metabolic capabilities. Among these, CYP71 is a large family of plant cytochrome P450 monooxygenases. Typically, all members of a CYP family share at least $40 \%$ amino acid sequence identity and are divided into subfamilies (A, B, C, and so forth) composed of members with greater sequence identity and the identity between members of different subfamilies can be as low as 30\% (Chapple, 1998). In Arabidopsis, currently 45 members of the $C Y P 71$ family have been identified. In the present study, CYP71A 8 protein (spot no.6) was identified and share with 33\% amino acid sequence similarity with Mentha $x$ piperita. This protein are mainly involved in heme binding activity which contain a conserved sequence termed as the P450 signature motif, approximately 50 to 60 amino acids from their $\mathrm{C}$ termini. The Cys located within this sequence serves as the ligand for the ferriprotoporphyrin IX (heme) prosthetic group (Schuler, 1996). This heme contains the B'-C turn, the central I helix, $\beta 6-1 / \beta 1-4$, the Cys-pocket, and the amino terminal L helix and is covalently bound to the invariant cysteine found in a $\beta$ bulge region called the Cys-pocket. The $\beta$-bulge appears to serve as a major role of enveloping the cysteine in a hydrophobic environment. Three residues besides the cysteine are strictly conserved and these conserved regions of the enzymes are found in the core of the protein, probably representing the conservation of regions important for proper protein folding and this perhaps supports other various processes such as lipid, nitrogen and secondary metabolism in plants against stress.

\subsection{KDa heat shock protein (sHSP)}

Plants are characterized by unique and diverse sHSPs that may reflect their need to rapidly adapt to ever changing environmental conditions. sHSPs are usually undetectable in vegetative tissue under normal growth conditions, but can be induced by developmental stimuli or by environmental stresses. HSPs as a major class of responsive proteins play a role via cross-talk with other mechanisms and function 
Table 1. Differentially responsive proteins identified after long term salt response in S. maritima leaves by MALDI-TOF analysis.

\begin{tabular}{|c|c|c|c|c|c|c|c|c|c|}
\hline Spot No. & $\begin{array}{l}\text { Thr. pI/MW } \\
\text { (KDa) }\end{array}$ & $\begin{array}{l}\text { Exp. pI/MW } \\
\text { (KDa) }\end{array}$ & Homology Proteins & Plant Species & $\begin{array}{c}\text { Sequence } \\
\text { Coverage } \\
\%\end{array}$ & Mascot Score & $\begin{array}{l}\text { Peptides } \\
\text { Matched }\end{array}$ & $\begin{array}{c}\% \\
\text { Identity }\end{array}$ & $\begin{array}{l}\text { Accession } \\
\text { No. }\end{array}$ \\
\hline 1 & $\begin{array}{c}6.95 / \\
230.46\end{array}$ & $\begin{array}{c}6.96 / \\
230.75\end{array}$ & $\begin{array}{l}\text { Ras related protein } \\
\qquad a b 2 B\end{array}$ & Zea mays & 54 & 60 & 112 & 100 & NP_001106234 \\
\hline 3 & $\begin{array}{c}7.98 / \\
75.035\end{array}$ & $\begin{array}{c}7.98 / \\
75.435\end{array}$ & $\begin{array}{l}\text { SNARE interacting } \\
\text { protein } K E U L E\end{array}$ & $\begin{array}{c}\text { Arabidopsis } \\
\text { thaliana }\end{array}$ & 29 & 44 & 199 & 99 & AAK01291 \\
\hline 4 & $\begin{array}{c}5.24 / \\
126.76\end{array}$ & $\begin{array}{c}5.24 / \\
126.05\end{array}$ & $\begin{array}{l}\text { Sister chromatid } \\
\text { cohesion protein } 3\end{array}$ & $\begin{array}{c}\text { Arabidopsis } \\
\text { thaliana }\end{array}$ & 13 & 38 & 134 & 100 & NP_566119 \\
\hline 5 & $\begin{array}{c}7.98 / \\
75.035\end{array}$ & $\begin{array}{c}7.98 / \\
75.435\end{array}$ & $\begin{array}{l}\text { SNARE interacting } \\
\text { protein } K E U L E\end{array}$ & $\begin{array}{c}\text { Arabidopsis } \\
\text { thaliana }\end{array}$ & 29 & 45 & 199 & 99 & AAK01291 \\
\hline 6 & $\begin{array}{c}9.34 / \\
57.176\end{array}$ & $\begin{array}{c}9.34 / \\
57.405\end{array}$ & Cytochrome P450 71A8 & $\begin{array}{l}\text { Menthax } \\
\text { piperita }\end{array}$ & 33 & 50 & 166 & 100 & Q42716 \\
\hline 12 & $\begin{array}{c}6.31 / \\
16.638\end{array}$ & $\begin{array}{c}6.32 / \\
16.696\end{array}$ & $\begin{array}{l}\text { 16.6KDa heat shock } \\
\text { protein }\end{array}$ & $\begin{array}{c}\text { Oryza sativa } \\
\text { Japonica } \\
\text { Group }\end{array}$ & 32 & 53 & 49 & 100 & XP_015620983 \\
\hline
\end{tabular}

Control

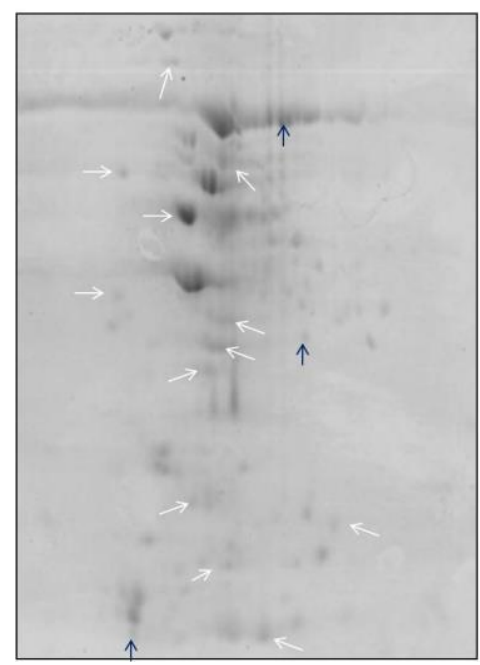

Treated

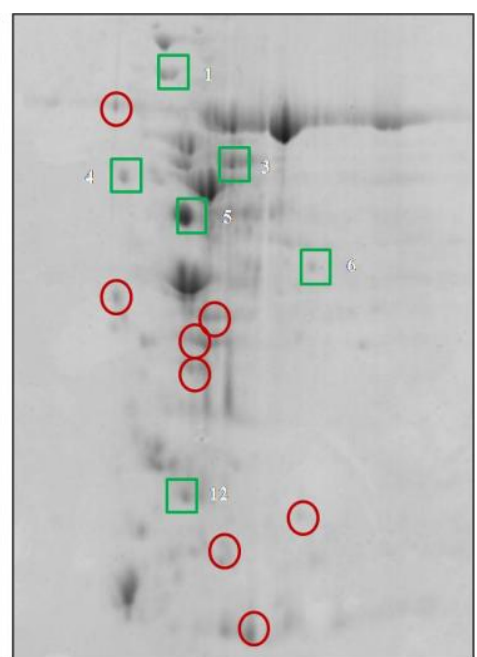

Fig 1. Representative two-dimensional gel electrophoresis (2DE) gels of proteins extracted from leaves of S. maritima. First dimension was performed using $200 \mu \mathrm{g}$ total soluble proteins on linear gradient IPG strip with $\mathrm{pH} 3-10$. In the second dimension, $12 \%$ SDS-PAGE gels were used and proteins were visualized using Coomassie Brilliant Blue (CBB) between control and $200 \mathrm{mM} \mathrm{NaCl}$ treated respectively. Both red circle and green box indicates that protein changes reproducibly and significantly under salt treatments and white arrows mark the position of the same proteins from the control while green box denotes the identified protein spots by MALDI-TOF/MS analysis. Blue upward arrows indicate the proteins spot present only in the control. See Table 1 for the list of identified proteins.

Table 2. Location, role and function of identified proteins.

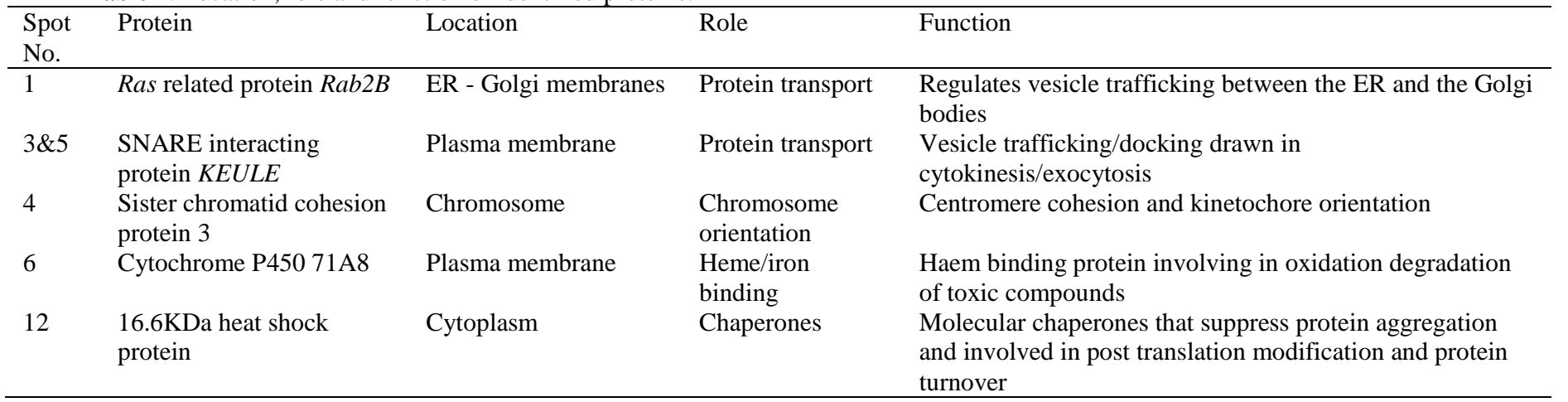



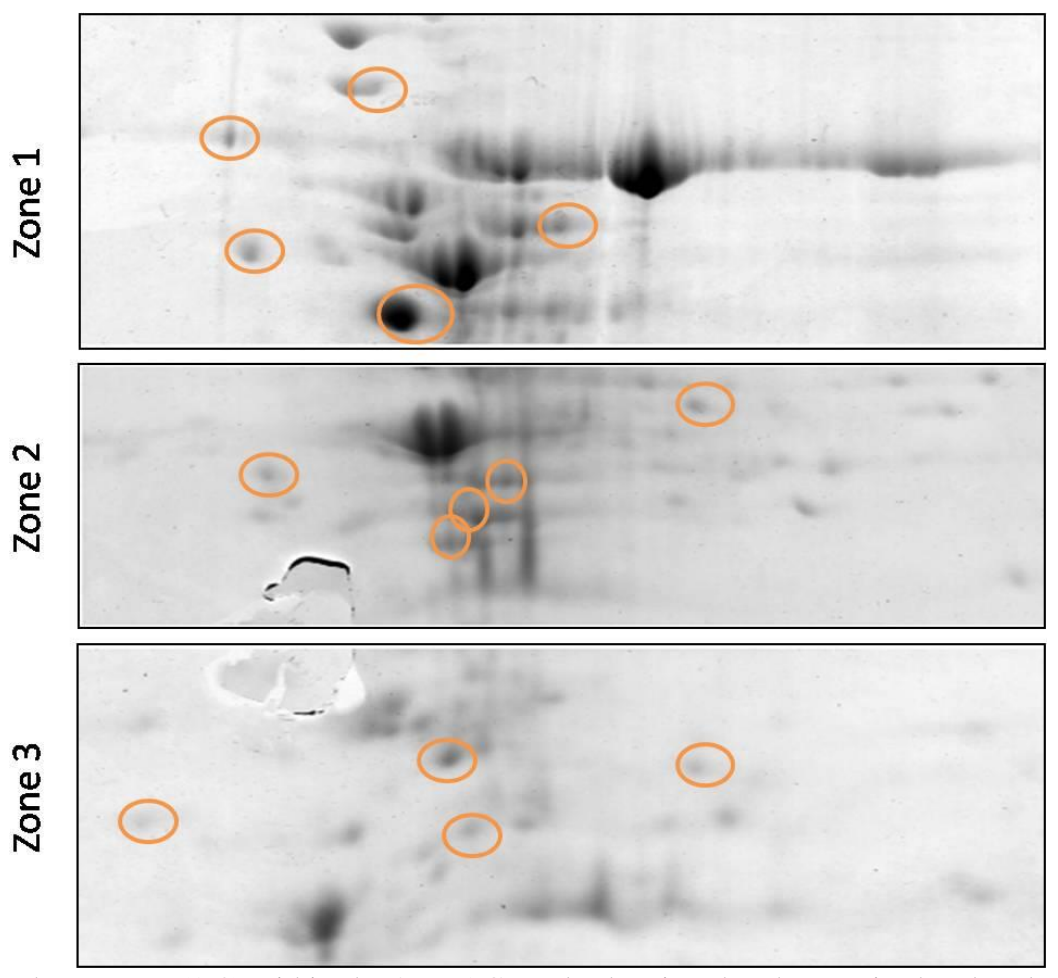

Fig 2. Enlargement of the three zones (1-3) within the 2D-PAGE gels showing the changes in the abundance of the protein spots identified upon salt-exposure of $S$. maritima. For each zone, orange circle indicate 2 fold change spot position on the gel at a given salt concentration compared with the control.

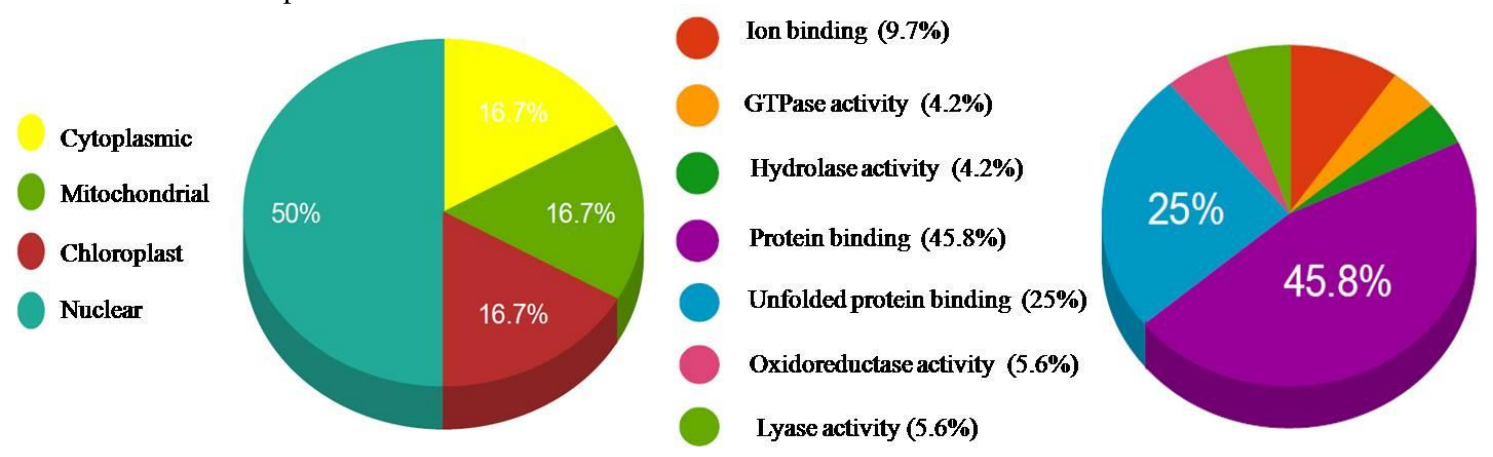

Fig 3. Localization and functional distribution of identified proteins expressed in leaf of $S$. maritima after $\mathrm{NaCl}$ treatment (http://cello.life.nctu.edu.tw/cello2go/).

synergistically with other components to decrease cellular damage (Wang et al., 2004). It acts as molecular chaperons in aiding the renaturation of damaged proteins to maintain protein conformation and cellular homeostasis against stress. HSPs are classified into five classes according to their approximate molecular weight: (1) Hsp100, (2) Hsp90, (3) Hsp70, (4) Hsp60 and (5) small heat-shock proteins (sHsps) (Whaibi, 2011). sHSPs represent a family of 12 to $42 \mathrm{kDa}$ proteins sharing a conserved 90 amino acid C-terminal domain called $\alpha$ crystallin domain present in most of the organisms (waters et al., 1996). sHSPs are known to form multimers consisting of 9 to 30 monomers and to function as ATP-independent chaperones to prevent irreversible protein aggregation of denatured proteins and facilitate subsequent protein renaturation in cooperation with ATP-dependent chaperones. sHsps cannot refold non-native proteins, but they can bind to partially folded or denatured substrates proteins, preventing irreversible unfolding or wrong protein aggregation. Previous reports showed that the sHsp18.1 and sHsp16.9 isolated from Pisum sativum and wheat, as well as the sHsp16.6 from Synechocystis sp. PCC6803 involved in binding to unfolded proteins and allows further refolding by Hsp70/ Hsp100 complexes (Lee et al., 1998; Mogk et al., 2003). In this study, heat shock protein 16.6 (spot no.12) were up regulated by exposure to salinity, suggesting that this protein could play a role in protein folding \& assembly, signal transduction, and secondary metabolism, which are essential for cellular viability in plants to acquire salt tolerance.

\section{Materials and Methods}

\section{Plant growth and salt treatments}

S. maritima seeds were collected from an adult plant growing along the seashore of the mangrove coastal belt, Pichawaram, Chidambaram district in Tamilnadu. The seeds were germinated on vermiculite in plastic pots and allowed to grow for 3 months under natural day/night cycles in a greenhouse. The seedlings were watered with distilled water 
and nutrient medium alternatively. After 3 months, the plants were transferred to Modified Hoagland's solution (Sahu and Shaw, 2009) and grew hydroponically for a week. For finding the optimal salt concentration for treatment, different concentration of $\mathrm{NaCl}(100,200,300,400$ and $500 \mathrm{mM})$ were added to the nutrient medium and plants were grown for a period of 14 days in a growth chamber maintained at $24 \pm$ $3^{\circ} \mathrm{C}, 70-75 \%$ relative humidity with $14 \mathrm{~h}$ light $(200 \mu \mathrm{mol} \mathrm{m}$ $\left.\mathrm{s}^{-1}\right) / 10 \mathrm{~h}$ dark cycle. The untreated set maintained in Modified Hoagland's solution was considered as control. The media was changed every two days to avoid variations in nutrients and salt concentration and to avoid contamination.

Based on the results of this experiment, $200 \mathrm{mM} \mathrm{NaCl}$ was selected as the concentration for salt treatment before proteomics experiments. A set of plants were then treated with $200 \mathrm{mM} \mathrm{NaCl}$ for a period of 14 days in a growth chamber maintained at similar conditions. The untreated set maintained in Modified Hoagland's solution was considered as control. After 14 days of treatment, leaves from control and salt treated plants were harvested. Three independent biological replicates each comprising of tissue from 3-4 seedlings was prepared for proteomic analyses.

\section{Protein extraction}

The extraction procedure was based on Faurobert et al., 2007 with some modifications. Samples were weighed about $3 \mathrm{~g}$ of tissue was powdered in a mortar and pestle using liquid nitrogen. This was mixed with $15 \mathrm{ml}$ of the protein extraction buffer pH $8.0(700 \mathrm{mM}$ sucrose, $500 \mathrm{mM}$ Tris-Hcl, $50 \mathrm{mM}$ EDTA, $100 \mathrm{mM} \mathrm{KCl}, 2 \%(\mathrm{v} / \mathrm{v}) \beta$-mercaptoethanol and $1 \mathrm{mM}$ PMSF). After $10 \mathrm{~min}$. of incubation on ice, equal volume of Tris-saturated phenol was added and the mixture was vortexed well at room temperature for $10 \mathrm{~min}$ and centrifuged for $15 \mathrm{~min}$ at $5,500 \times \mathrm{g}$ and $4{ }^{\circ} \mathrm{C}$. The centrifugation step was repeated after the upper phenolic phase containing soluble proteins had been removed carefully and the initial sample volume was restored by addition of extraction buffer. The proteins extracted in the resulting phenolic phase were precipitated at $-20^{\circ} \mathrm{C}$ overnight by adding $100 \mathrm{mM}$ ammonium acetate in methanol (precipitating solution). This mixture was then centrifuged for $20 \mathrm{~min}$. at $5,500 \times \mathrm{g}$ and $4{ }^{\circ} \mathrm{C}$ and the pellet was resuspended in $5 \mathrm{ml}$ of the precipitating solution before re-centrifugation. This latter step was repeated three times. The pellet was then rinsed with $80 \%(\mathrm{v} / \mathrm{v})$ ice cold acetone, re-centrifuged, and air dried at room temperature for $15 \mathrm{~min}$. Finally, the pellet were lyophilized under vacuum and then dissolved in protein rehydration buffer (8 M urea, $2 \%(\mathrm{w} / \mathrm{v})$ CHAPS, $0.2 \%(\mathrm{v} / \mathrm{v})$ ampholytes (3-10 Biorad), $50 \mathrm{mM}$ DTT, and 2-4 mg Bromophenol Blue). The protein concentration of each pellet was determined using BCA method (Smith et al., 1985) and bovine serum albumin (BSA) was used as a standard.

\section{Two-dimensional gel electrophoresis}

The extracted proteins were separated in the first dimension by isoelectric focusing (IEF). Before IEF was performed, $200 \mu \mathrm{g}(200 \mu \mathrm{l})$ protein suspensions were vortexed and centrifuged for $5 \mathrm{~min}$ at $12,000 \times \mathrm{g}$ and $4{ }^{\circ} \mathrm{C}$. After centrifugation, protein samples were pipetted in to rehydration tray and carefully kept the $11 \mathrm{~cm}$ IPG Strip $(\mathrm{pH} 3-$ 10 , Biorad) on the protein sample without air bubbles at room temperature. IEF was carried out for $5 \mathrm{~h}$ with $11 \mathrm{~cm}$ dry gel strips (Protean i12 IEF, Biorad) with a current limit of $50 \mu \mathrm{A} /$ strip followed by focusing in four steps $250 \mathrm{~V}$ (20 $\mathrm{min})$, $8000 \mathrm{~V}$ (1 hr), $8000 \mathrm{~V}$ (26000 v/hrs), and $750 \mathrm{~V}$ (hold). Gel strips were then equilibrated for $20 \mathrm{~min}$. with a solution containing $0.375 \mathrm{mM}$ Tris- $\mathrm{HCl}(\mathrm{pH} 8.8), 6 \mathrm{M}$ urea, $20 \%(\mathrm{v} / \mathrm{v})$ glycerol, 2\% (w/v) SDS, 2\% (w/v) DTT. A second equilibration was carried out using the same solution in which DTT was replaced by $2.5 \%(\mathrm{w} / \mathrm{v})$ iodoacetamide. Equilibrated IPG strips were then horizontally placed on a $12 \%$ Tricine SDS-PAGE gel and sealed with a solution containing $0.5 \%$ agarose and Bromophenol Blue. SDS-PAGE was carried out at $200 \mathrm{~V}$ for $1 \mathrm{hr}$ at $25^{\circ} \mathrm{C}$ using protean gel electrophoresis unit (Biorad).

\section{Protein staining, scanning and image analysis}

Two-dimensional (2D) gels were stained overnight with Coomassie Brilliant Blue (0.1\% (w/v) CBB-G250). Gels were carefully destained and again washed with distilled water to remove the background due to staining. The $2 \mathrm{DE}$ gels were scanned using a GS 800 calibrated densitometer (Biorad) at 600 dpi resolution and images were stored as .tif files. For spot detection and volume quantification, .tif files were transformed into .mel files and analyzed using PDQuest analysis software v8.0 (Biorad).Three images of three independent biological replicates of leaves exposed to salinity were grouped to calculate the mean volume of all the individual protein spots. Following automatic spot detection, gel images were carefully edited and one of the gel images was selected as a reference gel before spot matching. The spot abundance was normalized as relative volume according to the normalization method provided by the software to obtain the individual relative spot volume (\%), i.e. the spot volume of one spot in relation to the sum of all detected spots on the gel. This method eliminates eventual protein loading differences.

\section{MALDI-TOF analysis}

Gel pieces, each containing a salt responsive protein spot, were excised manually, destained two times with $20 \mu \mathrm{l}$ of $50 \%$

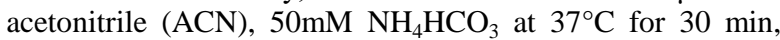
dehydrated by adding $10 \mu \mathrm{l}$ ACN and dried. $20 \mu \mathrm{g} / \mathrm{ml}$ sequencing grade trypsin (promega) was added and after 30 minutes incubation on ice remaining trypsin solution was discarded. Digestion was continued at $37^{\circ} \mathrm{C}$ for overnight and stopped by adding $0.1 \%$ TFA and $50 \%$ ACN. Tryptic peptides were extracted with two times $20 \mu 150 \% \mathrm{ACN}, 0.1 \%$ formic acid (FA) for $30 \mathrm{~min}$ at $37^{\circ} \mathrm{C}$ and $10 \mu \mathrm{l} \mathrm{ACN}$ for 30 min. at room temperature. All extracts were dried in a vacuum centrifuge. MALDI-TOF analysis was started by resolubilizing dried samples in $2 \mu \mathrm{l}$ of $2 \mathrm{mg} / \mathrm{ml} \alpha$-cyano-4hydroxycinnamic acid (CHCA), 50\% ACN, and 0.1\% TFA. $1 \mu 1$ of the solution was spotted onto a stainless steel target and analyzed with a mass spectrometer.

\section{Database analysis}

Mass spectrometric data were analyzed by Mascot search engine (www.matrixscience.com) with carbamidomethylation of cysteine as static and oxidation of methionine as variable modification against the Swiss Prot and NCBInr Database. At least two peptides with a Mascot peptide ion score higher than 35 were used as a threshold for protein identification. Localization and molecular function of identified proteins were analyzed using CELLO2Go (http://cello.life.nctu.edu.tw/cello2go/). 


\section{Conclusion}

In the present study, we provided a comprehensive proteome dynamics of the leaves in the halophyte $S$. maritima under salt conditions. 18 proteins were found to be differentially expressing, showing more than a 2-fold change in abundance and 6 of them were identified by MALDI-TOF/MS analysis. Our results indicated that proteins involved in protein folding, assembly, chromosome segregation, cell maintenance, iron binding and also proteins involved in trafficking could be vital in salt stress tolerance in S. maritima. Further analysis of salt responsive proteins from this species would unravel novel mechanisms of salt stress tolerance in plants.

\section{Acknowledgements}

This work was carried out with a grant from Department of Biotechnology (DBT), Government of India. Thanks to Indian Institute of Science, Bangalore for helping the MALDI-TOF/MS analysis for the protein spots and also thanks to Jenifer and Rani, MSSRF for their support.

\section{References}

Ahmad P, Prasad MNV (eds.) (2012) Abiotic stress responses in plants: metabolism, productivity and sustainability. Springer, New York.

Askari H, Edqvist J, Hajheidari M, KafiM, Salekdeh GH (2006) Effects of salinity levels on proteome of Suaeda aegyptiaca leaves. Proteomics. 6(8):2542-54.

Assaad FF, Huet Y, Mayer U, Jurgens G (2001) The cytokinesis gene KEULE encodes a Secl protein that binds the syntaxin KNOLLE. J. Cell Biol. 152(3):531-43.

Batch WE (1990) Small GTP-binding proteins in vesicular transport. Trends Biochem Sci. 15(12):473-77.

Biggins S, Murray AW (1998) Sister chromatid cohesion in mitosis. Curr Opin Cell Biol. 10(6): 769-75.

Bock JB, Matern HT, Peden AA, Scheller RH (2001) A genomic perspective on membrane compartment organization. Nature. 409(6882):839-41.

Chapple C (1998) Molecular genetic analysis of plant cytochrome P450-dependent monooxygenases. Annu. Rev. Plant Physiol. Plant Mol. Biol. 49:311-43.

Cheng T, Chen J, Zhang J, ShiS, Zhou Y, Lu L, Wang P, Jiang Z, Yang J, Zhang S, Shi J (2015) Physiological and proteomic analyses of leaves from the halophyte Tangut Nitraria reveals diverse response pathways critical for high salinity tolerance. Front Plant Sci. 6(30):1-13.

Debez A, Braun HP, Pich A, Taamalli W, Koyro HW, Abdelly C, Huchzermeyer B (2012) Proteomic and physiological responses of the halophyte Cakile maritima to moderate salinity at the germinative and vegetative stages. J. Proteomics. 75:5667-94.

Fasshauer D, Sutton RB, Brunger AT, Jahn R (1998) Conserved structural features of the synaptic fusion complex: SNARE proteins reclassified as Q- and RSNAREs. Proc Natl Acad Sci USA. 95(26):15781-86.

Faurobert M, Pelpoir E, Chaib J (2007) In Thiellement H, Zivy M, Damerval C, Méchin v (eds) Phenol extraction of proteins for proteomic studies of recalcitrant plant tissues. Plant Proteomics: Methods and Protocols. 335: 9-14.

Flowers TJ, Colmer TD (2008) Salinity tolerance in halophytes. New Phytol.179:945-63.

Gagneul D, Ainouche A, Duhazé C, Lugan R, Larher FR, Bouchereau A (2007) A reassessment of the function of the so called compatible solutes in the halophytic
Plumbaginaceae limoniumlatifolium. Plant Physiol. 144:1598-1611.

Ghosh D, Xu J (2014) Abiotic stress responses in plant roots: a proteomics perspective. Front Plant Sci. 5(6):1-13.

Golldack D, Li C, Mohan H, Probst N (2014) Tolerance to drought and salt stress in plants: unraveling the signaling networks. Front Plant Sci. 5(151):1-10.

Gupta B, Huang B (2014) Mechanism of salinity tolerance in plants: physiological, biochemical, and molecular characterization. Int J Genomics. 1-18.

Hasemann CA, Kurumbail RG, Boddupalli SS, Peterson JA, Deisenhofer J (1995) Structure and function of cytochromes P450: a comparative analysis of three crystal structures. Structure. 3(1):41-62.

Jahn R, Scheller RH (2006) SNAREs: engines for membrane fusion. Nat Rev Mol Cell Biol. 7(9):631-43.

Jamil A, Riaz S, Ashraf M, Foolad MR (2011) Gene expression profiling of plants under salt stress. Crit Rev Plant Sci. 30(5):435-58.

Lee S, Prochaska DJ, Fang F, Barnum SR (1998) A 16.6kilodalton protein in the cyanobacterium Synechocystis $s p$. PCC 6803 plays a role in the heat shock response. Curr Microbiol. 37(6):403-07.

Lipka V, Kwon C, Panstruga R (2007) SNARE-ware: the role of SNARE-domain proteins in plant biology. Annu. Rev. Cell Dev. Biol. 23:147-74.

Mahajan S, Tuteja N (2005) Cold, salinity and drought stresses: an overview. Arch Biochem Biophys. 444(2):139158

Michaelis C, Ciosk R, Nasmyth K (1997) Cohesins: chromosomal proteins that prevent premature separation of sister chromatids. Cell. 91(1):35-45.

Mogk A, Schlieker C, Friedrich KL, Schonfeld HJ, Vierling E, Bukau B (2003) Refolding of substrates bound to small Hsps relies on a disaggregation reaction mediated most efficiently by ClpB/DnaK. J Biol Chem. 278(33):31033-42.

Ndimba BK, Chivasa S, Simony WJ, Slabas AR (2005) Identification of arabidopsis salt and osmotic stress responsive proteins using two dimensional difference gel electrophoresis and mass spectrophotometry. Proteomics. 5(16):4185-96

Palme K, Diefenthal T, Vingron M, Sander C, Schell J (1992) Molecular cloning and structural analysis of genes from Zea mays (L.) coding for members of the ras-related ypt gene family (small guanine nucleotide binding protein/ras gene superfamily). Proc Natl Acad Sci U S A. 89:787-91.

Parida AK, Das AB (2005) Salt tolerance and salinity effects on plants: a review. Ecotoxicol Environ Saf. 60(3):324-49.

Parida AK, Jha B (2010) Salt tolerance mechanisms in mangroves: a review. Trees. 24:199-217.

Pasierbek P, Fodermayr M, Jantsch V, Jantsch M, Schweizer D, Loidl J (2003) The Caenorhabditis elegans SCC-3 homologue is required for meiotic synapsis and for proper chromosome disjunction in mitosis and meiosis. Exp Cell Res. 289(2):245-255.

Pereira Leal JB, Seabra MC (2001) Evolution of the Rab family of small GTP-binding proteins. J Mol Biol. 313(4):889-901.

Ramani B, Reeck T, Debez A, Stelzer R, Huchzermeyer B, Schmidt A, Papenbrock J (2006) Aster tripolium L. and Sesuvium portulacastrum L.: two halophytes, two strategies to survive in saline habitats. Plant Physiol Biochem. 44(56):395-408.

Sahu BB, Shaw BP (2009) Isolation, identification and expression analysis of salt-induced genes in Suaeda maritima, a natural halophyte, using PCR-based 
suppression subtractive hybridization. BMC Plant Biol. 9(69):1-25.

Schuler MA (1996) The role of cytochrome P450 monooxygenases in plant insect interactions. Plant Physiol. 112:1411-19.

Shabala SN, Mackay AS (2011) Ion transport in halophytes. Adv Bot Res. 57:151-187.

Slama I, Abdelly C, Bouchereau A, Flowers T, Savoure A (2015) Diversity, distribution and roles of osmoprotective compounds accumulated in halophytes under abiotic stress. Ann Bot. 115(3): 433-47.

Smith PK, Krohn RI, Hermanson GT, Mallia AK, Gartner FH, Provenzano MD, Fujimoto EK, Goeke NM, Olson, BJ, Klenk, DC (1985) Measurement of protein using bicinchoninic acid. Anal Biochem. 150(1):76-85.

Sobhanian H, Motamed N, Jazii FR, Nakamura T, Komatsu S (2010) Salt stress induced differential proteome and metabolome response in the shoots of Aeluropus lagopoides (poaceae), a halophyte C4 plant. J. Proteome Res. 9(6):2882-97.

Sollner T, Whitehart SW, Brunner M, Erdjument-bromage H, Geromanos S, Tempst P, Rothman JE (1993) SNAP receptors implicated in vesicle targeting and fusion. Nature. 362(6418):318-24.

Suja George, Ajay Parida (2011) Over-expression of a Rab family GTPase from phreatophyte Prosopis juliflora confers tolerance to salt stress on transgenic tobacco. Mol Biol Rep. 38:1669-74.

Tada Y, Kashimura T (2009) Proteomic analysis of saltresponsive proteins in the mangrove plant, Bruguiera gymnorhiza. Plant Cell Physiol. 50(3):439-46.

Toth A, Ciosk R, Uhlmann F, Galova M, Schleiffer A, Nasmyth K (1999) Yeast cohesin complex requires a conserved protein, Ecolp $(C t f 7)$, to establish cohesion between sister chromatids during DNA replication. Genes Dev. 13(3):320-33.

Uzilday B, Ozgur R, Sekmen AH, Yildiztugay E, Turkan I (2015) Changes in the alternative electron sinks and antioxidant defense in chloroplasts of the extreme halophyte eutrema parvulum (Thellungiella parvula) under salinity. Ann. Bot. 115:449-63.
Vetter IR, Wittinghofer A (2001) The guanine nucleotidebinding switch in three dimensions. Science. 294(5545):1299-1304

Wang F, Yoder J, Antoshechkin I, Han M (2003) Caenorhabditis elegans EVL-14/PDS-5 and SCC-3 are essential for sister chromatid cohesion in meiosis and mitosis. Mol Cell Biol. 23(21): 7698-7707.

Wang J, Meng Y, Li B, Ma X, Lai Y, Si E, Yang K, Xu X, Shang X, Wang H, Wang D (2015) Physiological and proteomic analyses of salt stress response in the halophyte Halogeton glomeratus. Plant Cell Environ. 38:655-69.

Wang L, Liu X, Liang M, Tan F, Liang W, Chen Y, Lin YX, Huang L, Xing J, Chen W (2014) Proteomic analysis of salt-responsive proteins in the leaves of mangrove Kandelia candel during short-term stress. PLoS One. 9(1):1-15

Wang W, Vinocur B, Shoseyov O, Altman A (2004) Role of plant heat-shock proteins and molecular chaperones in the abiotic stress response. Trends Plant Sci. 9(5):244-52.

Wang X, Chang L, Wang B, Wang D, Li P, Wang L, Yi X, Huang Q, Peng M, Guo A (2013) Comparative proteomics of Thellungiella halophila leaves from plants subjected to salinity reveals the importance of chloroplastic starch and soluble sugars in halophyte salt tolerance. Mol Cell Proteomics. 12(8):2174-95.

Wang X, Fan P, Song H, Chen X, Li X, Li Y (2009) Comparative proteomic analysis of differentially expressed proteins in shoots of Salicornia europaea under different salinity. J Proteome Res. 8 (7):3331-45.

Waters ER, Lee GJ, Vierling E (1996) Evolution, structure and function of the small heat shock proteins in plants. $\mathrm{J}$ Exp Bot. 47(3):325-38.

Whaibi MH (2011) Plant heat-shock proteins: a mini review. Science. 23:139-150.

Yu J, Chen S, Zhao Q, Wang T, Yang C, Diaz C, Sun G, Dai S (2011) Physiological and proteomic analysis of salinity tolerance in Puccinellia tenuiflora. J Proteome Res. 10(9):3852-70.

Zerial M, McBride H (2001) Rab proteins as membrane organizers. Nat Rev Mol Cell Biol. 2(2):107-17.

Zhang H, Han B, Wang T, Chen SX, Li HY (2012) Mechanisms of plant salt response: insights from proteomics. J Proteome Res. 11(1):49-67. 